\title{
"Common Ophthalmic Preservatives in Soft Contact Lens Care Products: Benefits, Complications, and a Comparison to Non- Preserved Solutions" [Response to Letter]
}

\author{
Chelsea S Bradley (D) \\ Lindsay A Sicks (D) \\ Andrew D Pucker $\mathbb{D D}^{2}$ \\ 'Illinois College of Optometry, Chicago, \\ IL, USA; ${ }^{2}$ School of Optometry, \\ University of Alabama at Birmingham, \\ Birmingham, AL, USA
}

\section{Dear editor}

We thank Drs. Erdinest, London, and Levinger for their interest in our article discussing common ophthalmic preservatives in soft contact lens care products. ${ }^{1}$ We agree with the authors regarding the physiological effects of polyquaternium1, polyhexamethylene biguanide (PHMB), and/or borate on the ocular surface. While we did comment on the cytotoxicity of polyquaternium-1 affecting epithelial tight junctions, ${ }^{2}$ we did not specify this as oxidative stress or acknowledge the role of tumor necrosis factor alpha (TNF- $\alpha$ ) secretion, and we appreciate the added detail. Similarly, we acknowledged the role of PHMB alone and PHMB plus boric acid in causing significant corneal staining. ${ }^{3-7}$ As a literature review, the goal of our manuscript was to capture the current state of the field, and unfortunately, we were unable to include every available reference given the extensive scope of the article. Nevertheless, their comments do augment our report.

We also agree that it would be pertinent to consider the effects of MPS preservatives in relationship to corneal lenses, scleral lenses, and hybrid contact lenses. However, the purpose of our manuscript, as indicated by the title, was to highlight soft contact lens care products. Thus, while this topic was outside of the scope of our manuscript, we agree that a future review that focuses on specialty contact lens care products would benefit the community.

\section{Disclosure}

Dr. Lindsay A. Sicks reports personal fees and Honoraria (Speaker's Alliance) from Alcon Laboratories outside the submitted work. Dr. Andrew D. Pucker has received financial research support from Alcon Research, LLC, Art Optical, Bausch \& Lomb, Euclid Systems, Contamac, National Eye Institute, and Paragon Vision Sciences, and consulted for Alcon Research, LLC, CooperVision, EpiTech, EyeGate Pharmaceuticals, Inc, Kala Pharmaceuticals, Nevakar Inc, and Optikal Care Inc over the past three years. The authors report no other conflicts of interest in this communication. 


\section{References}

1. Bradley CS, Sicks LA, Pucker AD. Common ophthalmic preservatives in soft contact lens care products: benefits, complications, and a comparison to non-preserved solutions. Clin Optom. 2021;13:271. doi:10.2147/OPTO.S235679

2. Wright A, Mowrey-McKee M. Comparative cytotoxicity potential of soft contact lens care products. Cutan Ocul Toxicol. 2005;24(1):53-64. doi:10.1081/CUS-200046191

3. Jones L, MacDougall N, Sorbara LG. Asymptomatic corneal staining associated with the use of balafilcon silicone-hydrogel contact lenses disinfected with a polyaminopropyl biguanide-preserved care regimen. Optom Vis Sci. 2002;79(12):753-761. doi:10.1097/00006324200212000-00007
4. Andrasko G, Ryen K. Corneal staining and comfort observed with traditional and silicone hydrogel lenses and multipurpose solution combinations. Optometry. 2008;79(8):444-454. doi:10.1016/j. optm.2008.04.097

5. Young G, Keir N, Hunt C, Woods CA. Clinical evaluation of long-term users of two contact lens care preservative systems. Eye Contact Lens. 2009;35(2):50-58. doi:10.1097/ICL.0b013e31819630d3

6. Lipener C; Contact Lens Advisory in Scientific Studies (CLASS) group. A randomized clinical comparison of OPTI-FREE EXPRESS and ReNu MultiPLUS multipurpose lens care solutions. Adv Ther. 2009;26(4):435-446. doi:10.1007/s12325-009-0023-8

7. Choy CKM, Cho P, Boost MV. Cytotoxicity and effects on metabolism of contact lens care solutions on human corneal epithelium cells. Clin Exp Optom. 2012;95(2):198-206. doi:10.1111/j.1444-0938.2011.00687.x

Dove Medical Press encourages responsible, free and frank academic debate. The content of the Clinical Optometry 'letters to the editor' section does not necessarily represent the views of Dove Medical Press, its officers, agents, employees, related entities or the Clinical Optometry editors. While all reasonable steps have been taken to confirm the content of each letter, Dove Medical Press accepts no liability in respect of the content of any letter, nor is it responsible for the content and accuracy of any letter to the editor.

\section{Clinical Optometry}

\section{Publish your work in this journal}

Clinical Optometry is an international, peer-reviewed, open access journal publishing original research, basic science, clinical and epidemiological studies, reviews and evaluations on clinical optometry. All aspects of patient care are addressed within the journal as well as the practice of optometry including economic and business analyses. Basic and clinical research papers are published that cover

Submit your manuscript here: https://www.dovepress.com/clinical-optometry-journa all aspects of optics, refraction and its application to the theory and practice of optometry. The manuscript management system is completely online and includes a very quick and fair peer-review system, which is all easy to use. Visit http://www.dovepress.com/ testimonials.php to read real quotes from published authors. 